\title{
Relationship between smartphone use and sedentary behavior: a school-based study with adolescents
}

\author{
Relacionamento entre smartphone e comportamento sedentário: estudo de base \\ escolar com adolescentes
}

\section{AUTHOR'S \\ Camilo Luis Monteiro Lourenço ${ }^{1}$ (D) \\ Thiago Ferreira de Sousa ${ }^{2}$ (D) \\ Edmar Lacerda Mendes ${ }^{3}$ (D) \\ 1 Universidade Federal de Santa Catarina, \\ Programa de Pós-Graduação em Educação Física, \\ Florianópolis, Santa Catarina, Brasil. \\ 2 Universidade Federal do Recôncavo da Bahia, \\ Centro de Formação de Professores, Amargosa, \\ Bahia, Brasil. \\ 3 Universidade Federal do Triângulo Mineiro, \\ Departamento de Ciências do Esporte, Uberaba, \\ Minas Gerais, Brasil.}

\section{CORRESPONDING}

Camilo Luis Monteiro Lourenço

camilo_lourenco@outlook.com

Universidade Federal de Santa Catarina,

Bloco Administrativo do Centro de

Desportos, Trindade, Florianópolis,

Santa Catarina, Brasil.

ZC: 88040-900.

DOI

10.12820/rbafs. $24 \mathrm{e} 0076$

\section{(cc) BY-NC-SA}

This work is licensed under the Creative Commons Attribution-NonCommercial-ShareAlike 4.0 International License

\begin{abstract}
The aims of this study were a) to describe the smartphone use and sedentary behavior (SB) on typical weekdays and weekends, and b) to verify the association between smartphone use and SB among adolescents. This is a cross-sectional population school-based, which surveyed 984 students from Uberaba, Minas Gerais, in 2015. Gender-stratified analysis were performed using t-tests, Pearson's correlation $(\mathrm{r})$ and multiple linear regression $(\beta)$. Girls used more smartphones than boys (weekdays: 6.58 hrs vs. 5.29 hrs, $\mathrm{p}<0.001$; weekend: 7.81 hrs vs. $6.18 \mathrm{hrs}, \mathrm{p}<0.001$ ). Both genders used more smartphones in the weekend $(\mathrm{p}<0.001)$ than weekdays. SB was higher in girls than boys (weekdays: 5.34 hrs vs. 4.48 hrs, $\mathrm{p}<0.001$, weekend: 5.22 hrs vs. $4.38 \mathrm{hrs}, \mathrm{p}<0.001$ ). SB was higher for both genders at weekend $(\mathrm{p}<0.001)$ than on weekdays. Correlation between SB and smartphone use ranged from weak to moderate in both genders (weekdays: boys, $r=0.30$; girls, $r=0.17, p<0.001$; weekend: boys, $r=0.39$; girls, $r=0.17, p<0.001)$. Smartphone use was positively associated with SB during the weekdays (boys: $\beta=0.25$, girls: $\beta=0.19, \mathrm{p}<0.001$ ) and weekend (boys: $\beta=0.31$; girls: $\beta$ $=0.14, \mathrm{p}<0.001$ ). Girls showed greater SB and smartphone use than boys, regardless if compared on weekdays or weekend. SB and smartphone were positively associated in both genders.
\end{abstract}

Keywords: Sedentary lifestyle; Computers; Handheld; Cell phones; Health surveys.

RESUMO

Os objetivos deste estudo foram a) descrever o uso de smartphone e o comportamento sedentário (CS) em dias típicos de semana e final de semana (FDS) e, b) verificar a associação entre o uso de smartphone e o CS em adolescentes. Trata-se de um estudo transversal, com 984 escolares de Uberaba, Minas Gerais, conduzido em 2015. Para análises estratificadas por sexo, utilizou-se testes-t, correlação de Pearson ( $r$ ) e regressão linear múltipla ( $\beta$ ). Moças usavam mais o smartphone que os rapazes (semana: 6,58 vs. 5,29 horas, $p<0,001$; FDS: 7,81 vs. 6,18 horas, $p<0,001)$. Ambos os sexos usaram mais smartphone no FDS $(p<0,001)$. O CS foi maior nas moças que nos rapazes (semana: 5,34 vs. 4,48 horas, $p<0,001$; FDS: 5,22 vs. 4,38 horas, $p<$ 0,001). O CS foi maior no FDS, em ambos os sexos ( $p<0,001)$. A correlação entre CS e smartphone foi de fraca a moderada em ambos os sexos (semana: rapazes, $r=0,30$; moças, $r=0,17, p<0,001$; e FDS: rapazes, $r$ $=0,39 ;$ moças, $r=0,17, p<0,001)$. Uso de smartphone foi positivamente associado com CS durante a semana (rapazes: $\beta=0,25$; moças: $\beta=0,19, p<0,001$ ) e FDS (rapazes: $\beta=0,31$; moças: $\beta=0,14, p<0,001$ ). Moças apresentaram maior CS e uso de smartphone do que rapazes, independentemente se comparados na semana ou FDS. CS e uso de smartphones foram positivamente associados em ambos os sexos.

Palavras-chave: Estilo de vida sedentário; Computadores de mão; Telefone celular; Inquéritos epidemiológicos.

\section{Introduction}

Considering both the volume of sales ${ }^{1}$ and its technological resources ${ }^{2}$, smartphones are the technology most used every day ${ }^{3-6}$. Approximately 122 million smartphones had been sold worldwide in 2007, and that number increased from 1.4 billion in 2015 to 1.56 billion in $2018^{2}$. The growth of users is a global phenomenon. However, such growth is more expressive in economically emerging countries as Malaysia, China, and Brazil ${ }^{1}$. Smartphones, also known as all-in-one devices, are equipped with high-tech operating systems (e.g., Apple iOS, Google Android, Windows Phone) and advanced features (touch screen, camera, mobile phone, applications, digital assistants, task managers, and mobile internet). Their set of features makes them attractive and multitasking.

Teenagers stand out as the largest group of smartphone users. Approximately three-quarters of US adolescents have a cell phone, and almost half of these are smartphone-type mobile devices ${ }^{3}$. Among Asian adolescents, the prevalence of smartphone ownership was $40.6 \%$ in China, $55.7 \%$ in Hong Kong, $56.7 \%$ in 
Malaysia, 63.8\% in Japan, 67.2\% in the Philippines and $84.4 \%$ in South Korea ${ }^{4}$. A national survey showed that $54 \%, 81 \%$ and $87 \%$ of Brazilian adolescents, aged 10 to 14,15 to 17 and 18 or 19 years old, respectively, had a mobile phone for personal use in 2015. The proportion of ownership varied among students from private (94\%), and public schools $(67 \%)^{5}$. This age group also spends more time using smartphones. Hungarian teenagers were reported to spend an average of 4.48 hours per day using smartphones, and boys use less (3.4 hours) than girls (5.3 hours) ${ }^{6}$.

As a part of sedentary lifestyle, the sedentary behavior (SB), that is, any waking behavior characterized by an energy expenditure $\leq 1.5$ metabolic equivalents (METs), while in a sitting, reclining or lying position ${ }^{7}$ is considered a risk factor for the adolescents' health. SB has been associated with poor eating habits ${ }^{8}$, overweight and obesity ${ }^{9}$, increased cardiovascular and cardiometabolic risks in adolescents ${ }^{10}$, and risk of mortality in adulthood ${ }^{11}$. TV viewing, videogame and computer use, also known as screen time, is the most common way of $\mathrm{SB}$ assessment ${ }^{12,13}$. However, this operational definition can represent only part of the daily sedentary time ${ }^{14}$. Moreover, this usual parameter neglects the possibility of sedentary time in other screen activities. To illustrate this, a systematic review update ${ }^{15}$ of SB and health indicators in children and youth included search terms related to portable devices. In the review, Carson et al. ${ }^{15}$ assumed that young people use the technologies while they remain seated as when they say "[...] the present review included search terms to capture newer technologies, such as tablets and smartphones. [...] Portable devices, including cell phones, were included in the review under the assumption that children and youth primarily used these devices while seated". However, few studies included in the review used mobile devices as a measure of $\mathrm{SB}$, perhaps because it is believed that youth may not be primarily seated when using these devices. In contrast, this relationship has already been explored among adults ${ }^{16}$. The authors ${ }^{16}$ showed that cell phone use was associated with SB and that $81 \%$ of people use the cell phone while sitting or lying down.

As shown, smartphones are available, fashionable and highly used, especially among youth ${ }^{1-6}$. Also, studies on SB almost exclusively consider TV viewing and computer and/or video game use as measures of sedentarism ${ }^{12,13}$. Up to the moment, no study investigated the association between smartphone use and SB among Brazilian adolescents. Thus, following these gaps, this cross-sectional population-based study with school students had the aims: a) describe the smartphone use and $\mathrm{SB}$ and b) to verify the association between smartphone use and SB among adolescents.

\section{Methods}

The Assessment of Health Behavior and Lifestyle of Adolescents in Uberaba (ACtVU Study) was a cross-sectional school population-based study, including private and public schools to evaluate $\mathrm{SB}$ and associated factors in adolescents. The study was carried out between May and October of 2015. The city of Uberaba, Minas Gerais, Brazil, has $4,533.81 \mathrm{~km}^{2}$ and a population density of 65.29 inhabitants $/ \mathrm{km}^{2}$. The city has a high human development index $(0.772-14$ th in the state and 240th in the country), a Gini index of 0.50 , per capita income of $\mathrm{R} \$ 978.01$ and life expectancy of 75.7 years at birth ${ }^{17}$. We follow the STROBE Statement ${ }^{18}$ to report this paper (see supplementary material A).

Sample size was calculated considering: survey population $(\mathrm{N}=10,903)$, SB prevalence $(\mathrm{P}=50 \%)$, 95\% confidence level, acceptable sampling error (5\%), two-point effects design (deff $=2$ ) and addition of $20 \%$ and $10 \%$ for losses/refusals and confounding analyses, respectively. The estimated sample size was 979 adolescents - this sample size was calculated for the ACtVU Study project using Epi Info ${ }^{\text {TM }}$ 7. A post hoc tests revealed that the sample size achieved for the multiple regression models in this study reached values between 0.99 and 1.00 power $\left(\mathrm{G}^{*}\right.$ Power 3.1.9.2, parameters: $\mathrm{F}$ test; $\mathrm{R}^{2}=0.084$ to 0.162 ; effect size $\mathrm{f}^{2}=0.091$ to 0.193 ; sample size $=440$ [boys] and 554 [girls]; $\mathrm{n}$ predictors $=$ $5 ; \alpha=0.05)$. The selection process adopted was a twostage proportional conglomerate. In the first stage, 15 schools (public $=9$, private $=6$, out of 36 eligible) were drawn. In the second stage, 50 classes were randomly selected (out of 362 eligible). Eligibility criteria for this study included adolescents aged 14 to 18 years with valid data for all interest variables.

We use two previously validated questionnaires ${ }^{19,20}$. The Portable Technologies and Mobile Internet Questionnaire (Tecno-Q) was used to asses smartphone use. The Tecno-Q reproducibility test-retest showed Kappa values ranging from 0.77 to 1.00 and intraclass correlation coefficient ranging from 0.94 to $0.98^{19}$. The Behavior of Adolescents from Santa Catarina state Questionnaire (COMPAC) was used to assess SB. Test-retest reproducibility for the COMPAC Questionnaire ranged from 0.51 to $0.96^{20}$. Body mass index (BMI) 
was calculated as weight $(\mathrm{kg}) / \mathrm{height}(\mathrm{m})^{2}$ and then classified as low weight/eutrophic and overweight/obesity $^{21}$. A stadiometer (WCS ${ }^{\circledR}$, Wood Portable Compact, capacity $220 \mathrm{~cm}$, graduation $1 \mathrm{~mm}$ ) and a digital scale (Wiso ${ }^{\circledR}, \mathrm{w} 939$, capacity $180 \mathrm{~kg}$ ) were used in these measurements. A trained team of physical education students and teachers carried out all data collection.

Adolescents were asked about ownership (yes or not) and the type of cell phone (smartphone or other). Smartphone use was ascertained through the question: "How much time per day do you spend accessing the internet through the mobile phone?" "Access to the internet" was considered as the forms of access via wireless network (e.g. Wi-Fi ${ }^{\mathrm{TM}}$, mobile internet - 3G/4G modem etc.) for any use like check email, social networks (e.g. Facebook, Instagram etc.), online chatting, watching videos, listening to music and playing online. The access was considered only by the adolescent himself. SB was estimated by the sitting time, using the following question: "How much time do you spend sitting, talking to friends, playing cards or dominoes, talking on the phone, driving or as a passenger, reading or studying?". Adolescents were asked to disregard the time watching TV, using a computer and/or video game and playing games on the smartphone when responding to this question. Both questions were answered for a typical weekday (Monday to Friday) and weekend (Saturday or Sunday). The variables were assessed and analyzed in hours per day.

The covariates were age (full years), school type (public or private), school grade (first, second or third grade) and screen time (TV viewing and computer use). We selected these covariates to adjust for possible demographic, school characteristics and other sedentary screen activities that could act as confounding factors in the sample.

Descriptive characteristics including frequencies, means, standard deviations $( \pm)$, and $95 \%$ confidence intervals $(95 \% \mathrm{CI})$ were calculated for the total sample and school type groups. The Kolmogorov-Smirnov test was used to test the normality of the data. Independent and dependent $\mathrm{t}$-tests were used to compare means in continuous variables between gender and between weekdays and weekend days, respectively. Independent t-test was also used to compare time using smartphone and SB throughout the study sample. The Levene's test for equality of variance was used in the independent t-test. The chi-squared test $\left(\chi^{2}\right)$ was used to test the differences in the categorical variables.
Pearson correlation ( $r$ ) was used to test the correlation between smartphone use and sitting time (both in hours/day). The $r$ scores were interpreted ${ }^{22}$ as weak correlation $(r=0.10-0.29)$, moderate $(r=0.30-0.49)$ and substantial $(r=0.50-1.00)$. Simple and multiple linear regression models, adjusted for covariates, were constructed to quantify the angular coefficients $(\beta)$ between smartphone use and SB (both in hours/day). The $\beta$ coefficient represents how much the mean of $\mathrm{Y}(\mathrm{SB})$ change for an increase of one unit of variable $\mathrm{X}$ (smartphone). The adjusted models were tested for multicollinearity using the Variance Inflation Factor (VIF) and the tolerance $(1 / \mathrm{VIF}) . \mathrm{VIF}<10$ and $1 / \mathrm{VIF}>0.10$ were considered acceptable diagnostic values ${ }^{23}$. The normality of the residuals was verified using the single sample Kolmogorov-Smirnov test (D). The cross-validation of the models was verified by the adjusted $R^{2}\left(R^{2} a\right)$.

All analyses used recommended survey procedures and sample weighting to account for the clustered sampling design and to yield school population-based representative findings. We found inconsistent values for smartphone use and SB. Therefore, the data were cleaned and the analyses were adjusted to the average self-reported daily sleep time on weekdays (boys = $429.5 \mathrm{~min} /$ day; girls $=429.9 \mathrm{~min} /$ day $)$ and weekend (boys $=521.0 \mathrm{~min} /$ day; girls $=514.6 \mathrm{~min} /$ day) in our sample ${ }^{24}$. The inferential analyzes are shown separated by gender and weekdays (weekdays and weekend). Results were considered statistically significant if $\mathrm{p}<0.05$. The Epidata Entry (http://www.epidata.dk/) was used for double typing and data validation. The SPSS software version 21 (IBM $^{\circledR}$ SPSS $^{\circledR}$ Inc., Chicago, USA) was used to carry out the analyses.

The Secretariat of Education of the State of Minas Gerais and the Regional Superintendence of Education of Uberaba authorized this study. The local research ethics committee approved the protocol (number 994,772), and informed consent was obtained from all participants. The ACtVU Study was conducted following the Declaration of Helsinki.

\section{Results}

A total of 1,363 adolescents were invited to participate, 295 do not consent/assent to participate, and 84 were outside the age group or were missing data (BMI, $n$ $=67$ - for descriptive analysis). The final sample consisted of 984 participants, for the main analyses. The mean age was $15.93 \pm 1.13$ and $15.87 \pm 1.06$ years for boys and girls, respectively. Girls corresponded to 
$55.6 \%$ of the sample. The characteristics of the participants (gender, age group and BMI) are reported for the total sample and for school types (Table 1).

Nine out of ten adolescents (95.8\%) responded by owning a cell phone and almost all were smartphone $(95,3 \%)$. Overall and gender-stratified smartphone use and $\mathrm{SB}$ are shown in Table 2. The independent t-test showed significant differences between boys and girls in smartphone use for both weekdays $(\mathrm{p}<0.001)$ and weekends ( $p<0.001)$. There were significant differences between weekdays and weekends among boys ( $\mathrm{p}$ $0.001)$ and girls $(p<0.001)$. As for SB, there was a significant difference between boys and girls during both weekdays $(p<0.001)$ and weekends $(p<0.001)$. Both genders showed differences in SB between weekdays and weekends $(\mathrm{p}<0.001)$. Time using smartphone was superior to the sitting time both on weekdays and weekend days $(p<0.001)$ - Table 2 .

The overall correlation between SB and smart- phone use was weak and positive (weekdays: $\mathrm{r}=0.24$, $p<0.001$; weekend: $r=0.28, p<0.001)$. In boys, there was a weak positive correlation between smartphone use and SB in weekdays $(r=0.30, p<0.001)$ and a moderate positive correlation in weekends $(r=0.39, \mathrm{p}$ $<0.001)$. In girls, weak positive correlations were identified in both weekdays $(\mathrm{r}=0.17, \mathrm{p}<0.001)$ and weekends $(r=0.17, p<0.001)$.

Table 3 shows simple and multiple linear regression models. All adjusted linear regression models were significant ( $\mathrm{p}<0.001)$. In all models, a change of one unit in the time of smartphone use was positively associated with the change in SB. All adjusted regression models presented acceptable values for diagnostic statistics. Cross-validation values were low for all models (Table 3 ).

\section{Discussion}

This study described the use of smartphone and SB among adolescents and verified the relationship bet-

Table 1 - Sample characteristics, overall and stratified by school type. ACtVU Study 2015. Uberaba, Minas Gerais.

\begin{tabular}{|c|c|c|c|c|c|c|c|}
\hline \multirow{2}{*}{ Variables } & \multicolumn{2}{|r|}{ All } & \multicolumn{2}{|r|}{ Public } & \multicolumn{2}{|r|}{ Private } & \multirow{2}{*}{$\chi^{2}$} \\
\hline & $\mathrm{n}$ & $\%(95 \% \mathrm{CI})$ & $\mathrm{n}$ & $\%(95 \% \mathrm{CI})$ & $\mathrm{n}$ & $\%(95 \% \mathrm{CI})$ & \\
\hline Genders & & & & & & & 0.011 \\
\hline Boys & 440 & $44.4(39.6 ; 49.2)$ & 373 & $47.2(42.1 ; 52.4)$ & 67 & $34.2(28.0 ; 40.9)$ & \\
\hline Girls & 544 & $55.6(50.8 ; 60.4)$ & 413 & $52.8(47.6 ; 57.9)$ & 131 & $65.8(59.1 ; 72.0)$ & \\
\hline Age & & & & & & & $<0.001$ \\
\hline 14 to 16 years & 697 & $67.8(54.4 ; 78.9)$ & 533 & $65.5(50.2 ; 78.2)$ & 164 & $83.0(62.8 ; 93.4)$ & \\
\hline 17 to 18 years & 287 & $32.2(21.1 ; 45.6)$ & 253 & $34.5(21.8 ; 49.8)$ & 34 & $17.0(6.6 ; 37.2)$ & \\
\hline $\mathrm{BMI}^{\mathrm{w}}$ & & & & & & & 0.423 \\
\hline Low weight/eutrophic & 692 & $74.5(69.9 ; 78.6)$ & 553 & $74.7(69.7 ; 79.2)$ & 139 & $72.0(65.9 ; 77.3)$ & \\
\hline Overweight/obesity & 225 & $25.5(21.4 ; 30.1)$ & 170 & $25.3(20.8 ; 30.3)$ & 55 & $28.0(22.7 ; 34.1)$ & \\
\hline
\end{tabular}

$95 \% \mathrm{CI}=95 \%$ confidence interval; $\mathrm{BMI}=$ body mass index; w $=67$ missing data.

Table 2 - Overall and gender-stratified smartphone use and sedentary behavior. ACtVU Study 2015. Uberaba, Minas Gerais.

\begin{tabular}{|c|c|c|c|c|c|c|}
\hline \multirow{2}{*}{ Variables } & \multicolumn{2}{|c|}{ Weekdays } & \multicolumn{2}{|c|}{ Weekend } & \multirow{2}{*}{$\begin{array}{l}\text { Dependent } \\
\text { t-test }\end{array}$} & \multirow[b]{2}{*}{$\mathrm{p}$} \\
\hline & Mean & $\mathrm{SD}$ & Mean & $\mathrm{SD}$ & & \\
\hline \multicolumn{7}{|c|}{ Smartphone use (hours) } \\
\hline All & $6.62^{\dagger}$ & \pm 4.41 & $7.25^{\dagger}$ & \pm 4.42 & & \\
\hline Boys & 5.29 & \pm 3.95 & 6.18 & \pm 4.25 & -32.054 & $<0.001$ \\
\hline Girls & $6.58^{\S}$ & \pm 3.90 & $7.81^{\S}$ & \pm 4.31 & -45.390 & $<0.001$ \\
\hline \multicolumn{7}{|c|}{ Sedentary behavior (hours) } \\
\hline All & $5.11^{\dagger}$ & \pm 4.04 & $4.94^{\dagger}$ & \pm 3.95 & & \\
\hline Boys & 4.48 & \pm 3.64 & 4.38 & \pm 3.51 & 3.759 & $<0.001$ \\
\hline Girls & $5.34^{\S}$ & \pm 4.03 & $5.22^{\S}$ & \pm 4.11 & 4.364 & $<0.001$ \\
\hline
\end{tabular}

$\mathrm{SD}=$ standard deviation; Symbol $(\S)$ indicates significant independent t-test (boys vs. girls, all comparisons $\mathrm{p}<0.001)$; Levene's test $=$ smartphone use - weekdays $(\mathrm{F}=20.194, \mathrm{p}<0.001)$, weekend $(\mathrm{F}=1.137, \mathrm{p}=0.242)$; sedentary behavior - weekdays $(\mathrm{F}=273.245, \mathrm{p}<$ $0.001)$ weekend $(\mathrm{F}=694.655, \mathrm{p}<0.001)$; Symbol $(\dagger)$ indicates significant independent t-test (smartphone use vs. sedentary behavior, for "All sample", all comparisons $\mathrm{p}<0.001)$; Levene's test $=$ weekdays $(\mathrm{F}=1,279.3, \mathrm{p}<0.001)$, weekend $(\mathrm{F}=1,800.0, \mathrm{p}<0.001)$. 
Table 3 - Simple and multiple linear regression models of smartphone use and sedentary behavior. ACtVU Study 2015. Uberaba, Minas Gerais.

\begin{tabular}{|c|c|c|c|c|c|c|c|c|}
\hline \multirow{3}{*}{ Variables } & \multicolumn{4}{|c|}{ Simple linear regression* } & \multicolumn{4}{|c|}{ Multiple linear regression ${ }^{\ngtr *}$} \\
\hline & \multicolumn{2}{|l|}{ Weekdays } & \multicolumn{2}{|c|}{ Weekend } & \multicolumn{2}{|l|}{ Weekdays } & \multicolumn{2}{|l|}{ Weekend } \\
\hline & $\beta(95 \mathrm{CI} \%)$ & $\mathrm{R}^{2} \mathrm{a}$ & $\beta(95 \mathrm{CI} \%)$ & $\mathrm{R}^{2} \mathrm{a}$ & $\beta(95 \mathrm{CI} \%)$ & $\mathrm{R}^{2} \mathrm{a}$ & $\beta(95 \mathrm{CI} \%)$ & $\mathrm{R}^{2} \mathrm{a}$ \\
\hline Boys & $0.22(0.21 ; 0.23)$ & 0.06 & $0.24(0.23 ; 0.25)$ & 0.08 & $0.13(0.12 ; 0.15)^{\mathrm{A}}$ & 0.08 & $0.29(0.28 ; 0.31)^{\mathrm{C}}$ & 0.16 \\
\hline Girls & $0.13(0.12 ; 0.15)$ & 0.03 & $0.19(0.18 ; 0.20)$ & 0.05 & $0.18(0.16 ; 0.20)^{\mathrm{B}}$ & 0.16 & $0.20(0.18 ; 0.22)^{\mathrm{D}}$ & 0.12 \\
\hline
\end{tabular}

$\mathrm{B}=$ angular regression coefficient; $¥=$ multiple regression model adjusted to age (completed years), school type (public and private), school grade (1st, 2nd and 3rd) and screen time (TV viewing and computer use); $\mathrm{R}^{2} \mathrm{a}=$ adjusted $\mathrm{R}^{2} ; *$ All regression models presented $\mathrm{p}<0.001$ (single and multiple); Upper case letters ( ${ }^{\mathrm{A}, \mathrm{B}, \mathrm{C}, \mathrm{D}}$ ) indicate multiple linear regression models. Model diagnostics (range of values): Age: VIF $=1.0$ to 1.8 (models $\mathrm{B}$ and $\mathrm{D}$, respectively), $1 / \mathrm{FIV}=0.6$ to 1.0 (models $\mathrm{D}$ and $\mathrm{B}$, respectively); School type: VIF $=1.0$ to 1.2 (models A and $\mathrm{B}$, respectively), $1 / \mathrm{FIV}=0.9$ to 1.0 (models $\mathrm{B}$ and $\mathrm{A}$, respectively); School grade: $\mathrm{VIF}=1.4$ to 1.9 (models $\mathrm{A}$ and $\mathrm{D}$, respectively), $1 / \mathrm{FIV}=$ 0.5 to 0.9 (models B and A, respectively); Screen time: VIF $=1.0$ to 1.1 (models C and A, respectively), $1 /$ FIV $=0.9$ to 1.0 (models A and C, respectively); Normality of residuals: $\mathrm{D}=5.5$ to 10.7 (models $\mathrm{D}$ and $\mathrm{A}$, respectively, all models $\mathrm{p}<0.001$ ).

ween these two variables. The main findings of the current study were that SB and smartphone use time differed between boys and girls, during weekdays and weekend days. There were positive correlations, ranging from weak to moderate magnitudes, between smartphone use time and SB in adolescents. Finally, the multiple linear regression models confirmed the contribution of smartphone use time to sitting time in our sample.

In the present study, girls spent more time sitting than boys on weekdays. In a previous study with North-American adolescents, girls also spent more time sitting than boys for most of the comparisons (total time, race/ethnicity [non-Hispanic whites, non-Hispanic blacks, and Mexican-Americans], and body mass status [obese and non-obese] ${ }^{25}$. Specialists have considered high sitting time as a public health problem, especially among adolescents. High sitting time is associated with poor eating habits ${ }^{8}$, overweight and obesity ${ }^{9}$ and higher cardiovascular and cardiometabolic risk ${ }^{10}$. The definition of $\mathrm{SB}^{7}$, as known and used today, makes a wide range of daily activities to be classified as SB, even in a single postural position such as the sitting position, as adopted in this study. In the present study, some examples were used to illustrate the "sitting" position (e.g., playing cards or dominoes, talking on the phone, driving or travelling as a passenger, reading or studying). The mention of these activities in a single question is a factor that limits a more detailed identification of the differences in the SB pattern between the genders.

A systematic review of Brazilian studies ${ }^{12}$ pointed out that sitting time, apart from screen activities, had not been investigated among the 49 studies included. In the National Health and Nutrition Examination Survey (NHANES) ${ }^{25}$, conducted with American adolescents (median of 15.5 years old), the average sitting time was 7.5 hours per day, higher than our results. Also similar to the present study, the NHANES found that girls spent a long time in sitting position compared to boys. However, unlike the present study, the analyses in the NHANES considered sedentary activities in front of screens (TV or computer) as sitting time and did not stratify the results between weekdays and weekend days. Being sedentary is related to other behaviors ${ }^{8}$ and negative outcomes ${ }^{9,10}$ for the health of young people. In adults and the elderly, prolonged sitting time was associated with increased risk of allcause mortality and cardiometabolic diseases ${ }^{11}$, thus indicating the need to reduce opportunities to remain seated, especially in discretionary time, in early phases of life (i.e., childhood and adolescence).

Adolescents in the present study reported spending a considerable portion of time using smartphones. Our results were higher than those observed in a study with Hungarian adolescents ${ }^{26}$, in which girls also spent more time using smartphones than boys. Our results showed that the time using technology was higher on the weekend than on weekdays among boys and girls. Previous research reported that American boys and girls are always online, smartphones are facilitators, and the two groups have distinct profiles as to the purpose of using technology: girls use more social media and boys most often play games ${ }^{26}$. The present study was limited to investigating only the profile of time spent using smartphones, restricting the analysis and discussion of results regarding the difference between genders in the use of technology.

The positive correlations between sitting and time using smartphones presented in this study reinforce that time spent using smartphones must be taken into account in investigations on SB in adolescents. Furthermore, considering that access and popularity of 
screen-based technologies have increased among the pediatric population, as pointed out by Tremblay et al. ${ }^{14}$, future research on SB should focus on the use of media. It is necessary to consider the portable devices (e.g., smartphones) that can cause an increasingly common phenomenon: multitasking sedentarism ${ }^{15}$. According to these authors, young people can be in front of the TV, use the telephone (smartphone) and the computer at the same time. Thus, considering the expansion of commercialization of new media technologies such as smartphones especially among young people, future research should focus on investigating the impact of the time spent using these devices on SB.

In the present study, the multiple linear regressions show that time using smartphones was associated with $\mathrm{SB}$ among boys and girls. The substantial amount of time spent by adolescents with smartphone use identified in this study, especially on weekends, represents a worrying finding because the opportunity to remain seated would tend to rise. Fennel et al. ${ }^{16}$ also explored the relationship between cell phone use and SB. In an online survey, $81 \%$ of the adults ( $40 \pm 16$ years old) interviewed responded using their cell phone while sitting or lying down, contrasting with $8 \%$ who reported that this typically occurs while standing and $11 \%$ reported using their cell phone while walking or moving about. In addition, cell phone use was significantly and positively associated with $\mathrm{SB}(\beta=0.157, \mathrm{p}=0.002)$. While there has been an increasing effort to reduce the opportunities for younger people to remain seated ${ }^{27}$, especially in recreational time, smartphones appear to be against to this goal. Most intervention strategies to reduce $\mathrm{SB}$ include efforts to restrict the screen time television viewing, computer and/or video game available in rooms used by young people ${ }^{27}$. Although some success has been found to derive from the adoption of these strategies, future interventions may not be successful if they disregard the influence of portable devices on $\mathrm{SB}$, according to our results. Also, the attraction of young people to smartphones should also be considered, as it has been demonstrated that younger people (15-16 years old) are more likely to exhibit dependence on smartphones than young adults ( $\geq 19$ years old $)^{28}$.

To clarify some of the issues raised and not answered in this study, some directions are pointed out. Future studies should advance research on smartphone use and sedentary lifestyle, especially to elucidate the differences between genders and content and context of the use of portable devices. The following questions can be tested in the future studies: what type of media do adolescents consume on their smartphones? Does the media type influence SB? Do students remain in $\mathrm{SB}$ and using smartphones during school recess? Finally, as must have occurred with Fennel et al. ${ }^{16}$ (since they used a structured question similar to ours), our question about sitting time included "talking on the phone" as an example of sedentary activity, which can lead to misclassification. To deal with this, the question needs to be improved and longitudinal research studies (experimental or observational) can use objective (e.g., Microsoft SenseCam) or mixed methods (e.g., objective + interviews) to answer some that questions and best investigate adolescent behavior to identify and analyze the context of SB and the use of technologies.

This study has some limitations. First, the use of questionnaires to measure the variables of interest $\mathrm{SB}$ and time using smartphones - which may underestimate or overestimate the measures. For instance, a systematic review ${ }^{14}$ showed that studies using direct (i.e. accelerometers) measures found that young people spent a large portion of their day (up to 9 hours) being sedentary - higher than shown in our study. However, although the results of SB may be underestimated in our study, we emphasize that the $\mathrm{SB}$ that we investigated excluded screen time, that is, we evaluated only part of the sedentary time of adolescents - and the low values may be due to this. Moreover, the instruments used in this study had satisfactory psychometric validation indexes ${ }^{19,20}$. Second, as this is a observational study, causality can not be confirmed for use of smartphone and SB. Third, the low values of cross-validation of the multiple regression models indicate that caution is needed in what concerns the generalization of the results. Fourth, the situational use of smartphone (e.g., sitting, standing, or moving about ${ }^{16}$ was not evaluated in our study. Thus, we failed to confirm the findings of Fennel et al. ${ }^{16}$ and Barkley \& Lepp ${ }^{29}$ when they showed that adults use cell phones primarily while they are sitting (at $81 \%$ and $87 \%$ of the time, respectively). Additionally, since the time using smartphone was longer than the sedentary time in our sample, using the smartphone can be a sedentary activity but it is not exclusive to that. The strong points of this study were the short intervals of data collection, which minimize the behavioral bias of seasonality; the novelty in revealing that smartphone use is a predictor of SB; the sample that represented well the community of school adolescents according to schools types (public and private) in the municipality studied. 
In conclusion, girls showed greater SB and smartphone use than boys, regardless if compared on weekdays or weekend. SB and smartphone were positively associated in both genders.

\section{Conflict of interest}

The authors declare no conflict of interest.

\section{Acknowledgments}

To the Secretariat of Education of the State of Minas Gerais and the Regional Superintendence of Education of Uberaba. To the managers, teachers and adolescents of the participating schools. To the members of the collection team and the Núcleo de Estudos em Atividade Física \& Saúde (NEAFISA) of the Universidade Federal do Triângulo Mineiro. CLML received an M.Sc. scholarship (2014 to 2016) from Coordenação de Aperfeiçoamento de Pessoal de Nível Superior (CAPES).

\section{Author's contributions}

Lourenço CLM e Mendes EL, participated in the initial design and conduction of the ACtVU Study. All authors equally contributed to the design, analyses and interpretation of results, writing and critical review of this study.

\section{References}

1. Poushter J. Smartphone ownership and internet usage continues to climb in emerging economies. Pew Research Center's Global Attitudes Project. 2016. [citado em 2019 ago 19]. Disponível em: http://www.pewglobal.org/2016/02/22/ smartphone-ownership-and-internet-usage-continues-toclimb-in-emerging-economies/.

2. The Statistics Portal. Statistics and facts about Smartphones [online]. Statista. 2019. [citado em 2019 ago 19]. Disponível em: http://www.statista.com/topics/840/smartphones/.

3. Madden M, Lenhart A, Duggan M, Cortesi S, Gasser U. Teens and Technology 2013 [online]. Pew Research Center's Internet \& American Life Project. 2013. [citado em 2019 ago 19]. Disponível em: http://www.pewinternet. org/2013/03/13/teens-and-technology-2013/.

4. Mak KK, Lai CM, Watanabe H, Kim DI, Bahar N, Ramos $\mathrm{M}$, et al. Epidemiology of internet behaviors and addiction among adolescents in six Asian countries. Cyberpsychol Behav Soc Netw. 2014;17(11):720-8.

5. IBGE. Acesso à internet e à televisão e posse de telefone móvel celular para uso pessoal: 2015 [online]. Rio de Janeiro: IBGE; 2016. [citado em 2019 ago 19]. 87 p. Disponível em: https://biblioteca.ibge.gov.br/visualizacao/livros/liv99054.pdf.

6. Körmendi A. Smartphone usage among adolescents. Psychiatr Hung. 2015;30(3):297-302.

7. Tremblay MS, Aubert S, Barnes JD, Saunders TJ, Carson V, Latimer-Cheung AE, et al. Sedentary Behavior Research Network (SBRN) - Terminology consensus project process and outcome. Int J Behav Nutr Phys Act. 2017;14(1):75.

8. Lourenço CLM, Zanetti HR, Amorim PRS, Mota JAPS, Mendes EL. Comportamento sedentário em adolescentes: prevalência e fatores associados. $\mathrm{R}$ Bras $\mathrm{Ci}$ e Mov. 2018;26(3):23-32.
9. Silva Júnior LM, Santos AP, Souza OF, Farias ES. Prevalence of excess weight and associated factors in adolescents of private schools of an Amazonic urban area, Brazil. Rev Paul Pediatr. 2012;30(2):217-22.

10. Sisson SB, Shay CM, Camhi SM, Short KR, Whited T. Sitting and cardiometabolic risk factors in U.S. adolescents. J Allied Health. 2013;42(4):236-42.

11. Chau JY, Grunseit A, Midthjell K, Holmen J, Holmen TL, Bauman AE, et al. Sedentary behaviour and risk of mortality from all-causes and cardiometabolic diseases in adults: evidence from the HUNT3 population cohort. Br J Sports Med. 2015;49(11):737-42.

12. Guerra PH, Farias Júnior JC, Florindo AA. Comportamento sedentário em crianças e adolescentes brasileiros: revisão sistemática. Rev Saude Publica. 2016;50:9.

13. Okely AD, Salmon J, Vella S, Cliff D, Timperio A, Tremblay MS, et al. A systematic review to update the Australian physical activity guidelines for children and young people [online]. Report prepared for the Australian Government Department of Health. 2012. [citado em 2019 ago 19]. Disponível em: https://www.health.gov.au/internet/main/publishing.nsf/ ontent/3768EA4DC0BF11D0CA257BF0001ED77E /\$File/SR-ASBGCYP.pdf.

14. Tremblay MS, LeBlanc AG, Kho ME, Saunders TJ, Larouche $\mathrm{R}$, Colley RC, et al. Systematic review of sedentary behaviour and health indicators in school-aged children and youth. Int J Behav Nutr Phys Act. 2011;8:98.

15. Carson V, Hunter S, Kuzik N, Gray CE, Poitras VJ, Chaput JP, et al. Systematic review of sedentary behaviour and health indicators in school-aged children and youth: an update. Appl Physiol Nutr Metab. 2016;41(6 Suppl 3):S240-65.

16. Fennell C, Barkley JE, Lepp A. The relationship between cell phone use, physical activity, and sedentary behavior in adults aged 18-80. Comput Hum Behav. 2019;90:53-9.

17. PNUD, IPEA, FJP. Atlas do Desenvolvimento Humano no Brasil [online]. 2013. [citado em 2019 ago 19]. Disponível em: http://www.atlasbrasil.org.br/2013/pt/

18. von Elm E, Altman DG, Egger M, Pocock SJ, Gøtzsche PC, Vandenbroucke JP. The Strengthening the Reporting of Observational Studies in Epidemiology (STROBE) Statement: Guidelines for Reporting Observational Studies. PLoS Med. 2007;4(10):e296.

19. Lourenço CLM, Hélio Junior J, Zanetti HR, Mendes EL. Validade e reprodutibilidade de um questionário sobre uso de tecnologias portáteis e internet móvel em adolescentes brasileiros. Rev Tecnol Soc (Online). 2019. No prelo.

20. Silva KS, Lopes ADS, Hoefelmann LP, Cabral LGA, Bem MFL, Barros MVG, et al. Projeto COMPAC (Comportamentos dos Adolescentes Catarinenses): aspectos metodológicos, operacionais e éticos. Rev Bras Cineantropom Desempenho Hum. 2013;15(1):1-15.

21. Cole TJ, Bellizzi MC, Flegal KM, Dietz WH. Establishing a standard definition for child overweight and obesity worldwide: international survey. BMJ. 2000;320(7244):1240-3.

22. Cohen J. Statistical power analysis for the behavioral sciences. $2^{a}$ ed. Hillsdale, NJ: Lawrence Erlbaum Associates; 1988. $596 \mathrm{p}$.

23. Bowerman BL, O'Connell RT. Linear Statistical Models: An Applied Approach. 2a ed. Boston: PWS-Kent Pub. Co; 1990. $1024 \mathrm{p}$.

24. Van den Broeck J, Argeseanu CS, Eeckels R, Herbst K. Data cleaning: detecting, diagnosing, and editing data abnormalities. PLoS Med.2005;2(10):e267. 
25. Carson V, Staiano AE, Katzmarzyk PT. Physical activity, screen time, and sitting among US Adolescents. Pediatr Exerc Sci. 2015;27(1):151-9.

26. Lenhart A. Teens, Social Media \& Technology Overview 2015 [online]. Pew Research Center: Internet, Science \& Tech. 2015. [citado em 2019 ago. 19]. Disponível em: http:// www.pewinternet.org/2015/04/09/teens-social-mediatechnology-2015/.

27. Marsh S, Foley LS, Wilks DC, Maddison R. Familybased interventions for reducing sedentary time in youth: a systematic review of randomized controlled trials. Obes Rev. 2014;15(2):117-33.
28. Haug S, Castro RP, Kwon M, Filler A, Kowatsch T, Schaub MP. Smartphone use and smartphone addiction among young people in Switzerland. J Behav Addict. 2015;4(4):299-307.

29. Barkley JE, Lepp A. Mobile phone use among college students is a sedentary leisure behavior which may interfere with exercise. Comput Hum Behav. 2016;56:29-33.

Received: 30/04/2019

Approved: 26/09/2019

\section{Quote this article as:}

Lourenço CLM, Sousa TF, Mendes EL. Relationship between smartphone use and sedentary behavior: a school-based study with adolescents. Rev Bras Ati Fis Saúde. 2019;24:e0078. DOI: 10.12820/rbafs.24e0078 